


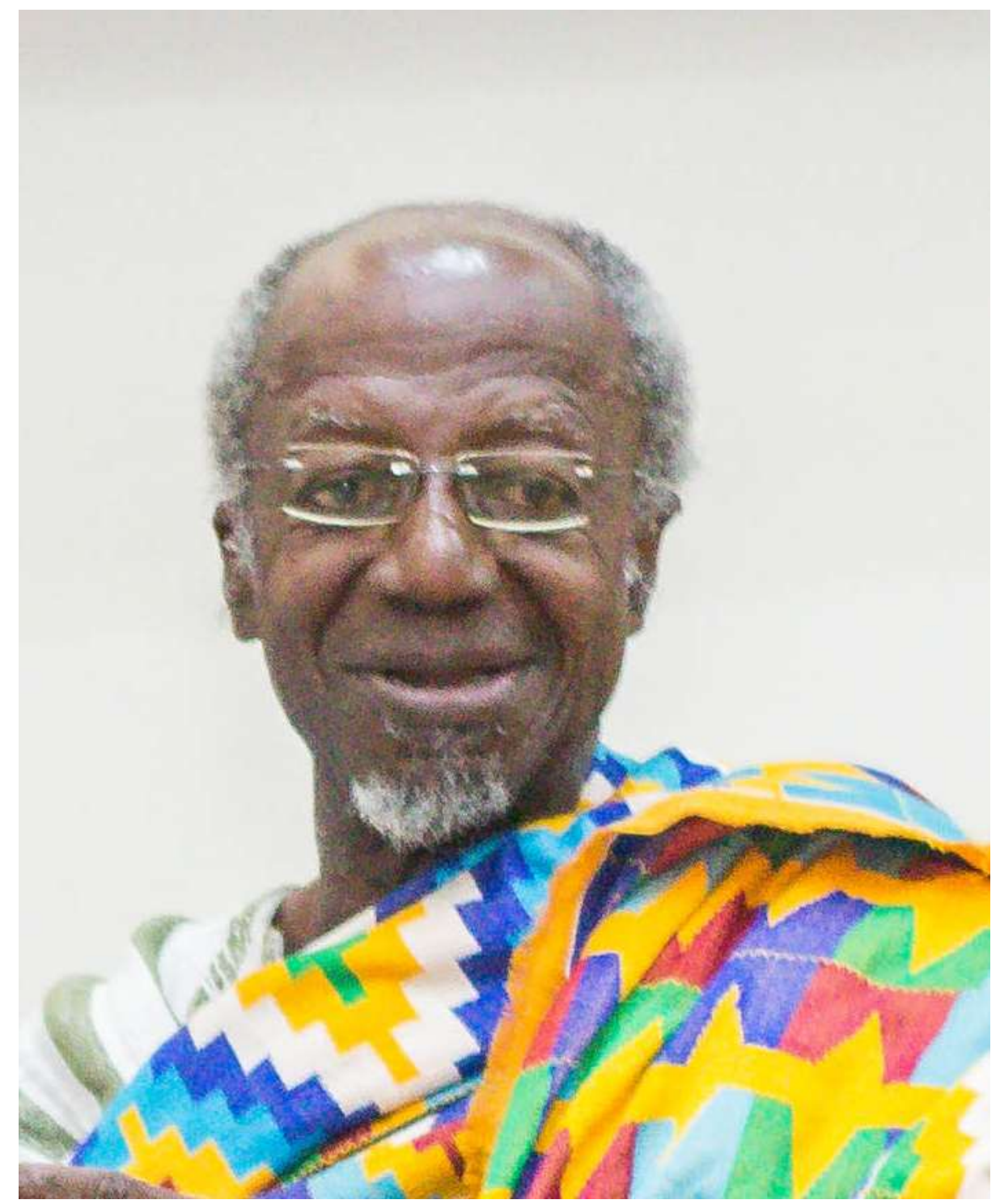

PROFESSOR ATTA GYAMFI BRITWUM 


\section{THE BILINGUAL LITERARY JOURNAL OF THE FACULTY OF ARTS UNIVERSITY OF CAPE COAST}

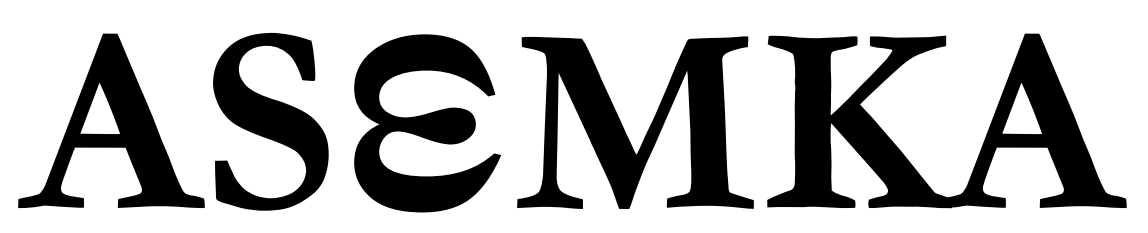

NUMBER 10

SEPTEMBER 2020

\section{EDITORIAL COMMITTEE}

Editor-in-Chief: Prof. Samuel Awuah-Nyamekye (Ph.D.)

Editor: $\quad$ Prof. Mawuloe Koffi Kodah (Ph.D.)

Associate Editors: Dr. Samuel Kwesi Nkansah

Dr. Mrs. Theresa Addai Munumkum

Dr. Isaac Mwinlaaru

Business Editor: Rev. Sr. Dr. Matilda Alice Nsiah

\section{EDITORIAL STAFF}

Mr. Stephen Owusu-Amoh

Mr. Isaac Kweku Grantson

\section{EDITORIAL ADVISORS}

Prof. Kwadwo Opoku-Agyemang, University of Cape Coast.

Prof. Joseph B. A. Afful, University of Cape Coast.

Prof. Raymond N. Osei, University of Cape Coast.

Prof. Richard V. Cudjoe, University of Cape Coast.

Prof. Victor K Yankah, University of Cape Coast.

Dr. Mousa Traore, University of Cape Coast. 


\section{ACKNOWLEDGEMENTS}

We acknowledge the contribution of the underlisted members of the Department of French who did preliminary editorial work on the papers:

Dr. Anthony Y.M. De-Souza (Chairman)

Prof. Raymond N. Osei

Prof. Mawuloe K. Kodah

Dr. Sylvester P. Krakue

Mr. Ofosu Addo-Danquah

Mr. Micheal Donkoh (Secretary)

\section{SUBSCRIPTION}

Assmka is published twice in the Academic year by the Faculty of Arts, University of Cape Coast. The annual out-of-Ghana subscription rate, including air-postage, is US\$29 for individuals, and US\$ 59 for institutions and libraries. Single issue rate for individuals is US\$18. Claims for copies not received must be made within three (3) months following an issue's publication. Correspondence should be addressed to:

The Editor, Assmka

Department of French

Faculty of Arts

College of Humanities and Legal Studies

University of Cape Coast

Cape Coast

Ghana, West Africa

Email: asemkajournal@ucc.edu.gh

\section{ADVERTISING}

Advertising rate, size specifications and related information are available upon request. Please, contact the General Editor for more information.

\section{SUBMISSIONS}

Assmka is an internationally-refereed journal of the Humanities. It publishes scholarly and imaginative articles in Literature, Language, and Culture generally, including, Orature, Film, Theatre, Music and Art. Essays, Interviews, Book Reviews, Poetry, Short Prose Fiction and Drama are welcome. Submitted manuscripts, in English and French, must be prepared in accordance with the most recent of APA or MLA style manual, where applicable. The author's identity and address may appear only on the cover- 
page and nowhere else within the submitted manuscript. All manuscripts should be submitted electronically through:

asemkajournal@ucc.edu.gh

Manuscript will be duly acknowledged within two (2) months of receiving them. Individuals whose works are accepted for publication may provide Assmka with a brief bio-data. The Editors cannot be held liable for lost or damaged manuscripts. Material published by Assmka does not necessarily represent the views of the Journal's Editors, Staff, Financial Supporters or the University of Cape Coast and its affiliates. These parties disavow any legal responsibility related to all submitted material.

\section{BACK ISSUES}

Back issues of Ascmka that are in stock may be ordered from the Editor at US\$20 per copy.

\section{GRANT SUPPORT}

Assmka is funded through grants from the Office of the Dean, Faculty of Arts; the Publications' Board; and the Office of the Vice-Chancellor, University of Cape Coast, Cape Coast, Ghana.

No part of this Journal may be reproduced, stored in a retrieval system, or transmitted in any manner whatsoever without express permission from the Editors, except in the case of brief quotations embodied in critical Articles and Reviews.

Copyright (C2020 by The Editors and The Faculty of Arts, University of Cape Coast. The cover and page design elements were inspired by the Adinkra symbols of Ghana. 


\section{DEDICATION \\ PROFESSOR ATTA GYAMFI BRITWUM}

Professor Britwum is a man of many parts. He is as much at home with Marxist Economic Theory and Feminist Sociological Thoughts, as he is with French and Francophone Literatures. He is a great teacher and Administrator of international acclaim. The Editors dedicate this special issue of Assmka to his honour. 


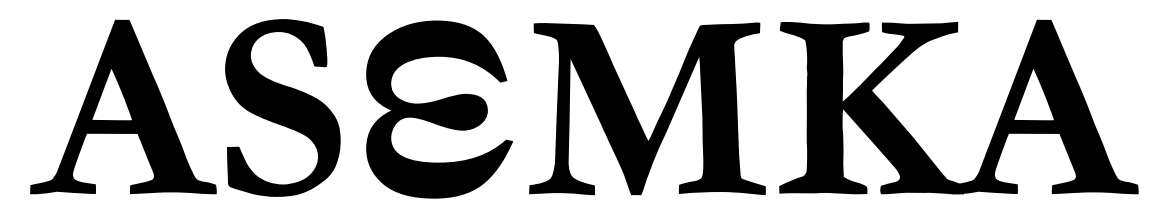

NUMBER 10

SEPTEMBER 2020 


\section{CONTENTS}

$\begin{array}{llll}\text { Editorial Committee } & \sim & \sim & \sim i i \\ \text { Editorial Staff } & \sim & \sim & \sim i i \\ \text { Editorial Advisors } & \sim & \sim & \sim i i \\ \text { Acknowledgements } & \sim & \sim & \sim i i i \\ \text { Subscription } & \sim & \sim & \sim i i i \\ \text { Advertising } & \sim & \sim & \sim i i i \\ \text { Submissions } & \sim & \sim & \sim i i i \\ \text { Back Issues } & \sim & \sim & \sim i v \\ \text { Grant Support } & \sim & \sim & \sim i v \\ \text { Dedication } \sim & \sim & \sim & \sim \\ \text { Foreword } \sim & \sim & \sim & \sim x \\ \text { Assmka: Editorial } & \sim & \sim & x i-x v i i\end{array}$

Articles

First Section - French

Britwum, A. G.

Insuffisances Théoriques Des Damnés De La Terre De

Frantz Fanon

$\sim$

$\sim 2-15$

Kodah, M. K.

Disculpation de Dieu dans le malheur des hommes:

Une lecture critique de Gouverneurs de la rosée de

Jacques Roumain $\sim \sim \sim 16-31$

Addo-Danquah, $O$.

Le récit de pensées: Une analyse comparative de Vol de nuit d'Antoine de Saint-Exupéry et La Condition humaine d'André Malraux

Kodah, M. K. \& Togoh, A. A. X.

Réactions des femmes face au conflit de genre dans C'est le soleil qui m'a brûlée et Tu t'appelleras Tanga de Calixthe Beyala

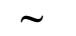

$\sim$

$\sim \quad 45-59$ 
Kudi, M. D.

La Littérature francophone face aux médias de télécommunication : Une nouvelle dynamique de la création romanesque, le cas de L'Énigme de retour et Tout bouge autour de moi de Dany Laferrière $\sim \quad$ 60-72

Gli, $M$.

Les faces du bonheur dans Vol de nuit d'Antoine de Saint-Exupéry $\sim \sim 73-85$

Krakue, S. P.

Christ haïtien : Gouverneurs de la rosée et La Bible $\sim 86-93$

Afari, E. S. K. \& Yegblemenawo, C. A. A.

Apports de la télésérie à l'amélioration de la compétence d'expression orale du FLE à l'école normale $\sim 94-116$

Bationo, J.-Cl.

Didactique de la littérature et littérature didactique:

l'exemple de la littérature africaine francophone en classe de langues étrangères au Burkina Faso

Second Section - English

Krakue, S. P.

Quod erat demonstrandum: A comparative study of narrative technique in Ama Ata Aidoo's Changes and Albert Camus'

Les justes (The Just Ones) 〜 $\sim$ $133-141$

Adjandeh, E. A.

Analysis of Wole Soyinka's Trials of Brother Jero in Relation to Ghanaian Religious Discourse

Sam, C. A.

Decolonizing the Postcolony: Of Men, Spatial Politics and the New Nation in WA Thiongo's Wizard of the Crow.

Kambou, M. K. \& Traore, S. A.

Manipulation and the popular uprising in Burkina Faso in 2014. 
De-Soura, A. Y.M.

Test-taking Strategies of University of Cape Coast Students of

French as a Foreign Language: a Case Study $\sim 191-216$

Kambou, M. K. \& Soma, L.

Local Culture and EFL Vocabulary Learning $\sim \quad 217-238$

Kabore, A. \& Nazortin, C.

Critical Analysis of the Place and Importance of Literature in the Teaching / Learning of English and in School Leaving Certificate Examination in Burkina Faso from 1985 to 2018

Malgoubri, I., Sawadogo, M. \& Kambou, M. K.

Digital Audio-visuals Aids and Listening in English as a

Foreign Language Classrooms

Osei, R. N. \& Inusah, $H$.

A Critique of the Images of Heaven in the Scriptures of the

Abrahamic Religions: An Existentialist Perspective $\sim$ 270- 282

Negedu, A. K.

Lexical Gaps and Ideological Shift in the Translation of

Chinua Achebe's Things Fall Apart as "Le Monde

S'effondre" in French $\sim \sim 283-297$

Talburt, $T$.

Political Transformation and Development in Africa:

Lessons from Achebe's Things Fall Apart

$\sim 298-313$ 


\section{FORWORD}

All the papers in this Volume were presented at a three-day Conference in honour of Professor Atta Gyamfi Britwum who turns eighty years in March 2021. Most of those years he spent at University of Cape Coast, having cut his teeth as a young lecturer in French language and Literature-in-French in 1974. After many years of an illustrious career in teaching, publication and extension, he bowed out at age seventy, but he didn't get the well-deserved rest he was entitled to; he continues to support his Department and the University as a whole. Today, Professor Britwum's name is associated with high standards of professionalism which earned him the nickname 'L'oracle'. Indeed, it is impossible to find another name universally acknowledged as embodying the excellence in French education offered at the Department of French, University of Cape Coast.

The decision to honour Professor Britwum couldn't have been taken at a more appropriate time. It was planned to coincide with the fiftieth anniversary of the publication of the Beautyful ones are not yet Born, Ayi Kwei Armah's first novel. Britwum never grew tired of reading, teaching and examining it. Such was his respect for Armah's craft. So, the three-day Conference was as much a celebration of Armah's contribution to the shaping of the African novel as it was a tribute to Professor Britwum's work as a teacher of literature of immense influence.

One only has to look at the titles of the papers published in this Volume to get an idea of how deep his influence runs at UCC and beyond. Most of the contributors once upon a time sat at the master's feet, but are now scholars in their own right keeping the flame of French scholarship burning bright (George Cooper: "Polished in a high degree, as each froggie ought to be/Now they sit on other logs, teaching other little frogs.") A good number of the papers are on Literature, nonetheless not limited to Armah's works. No Surprise there. Nevertheless, there are Language papers there too. No surprise here either, for the man to whose honour the Volume is dedicated is equally at home in both Language and Literature

\section{Lawrence $K$. Owusu-Ansah,}

Department of English, UCC.

A Disciple 


\section{$A S E M K A:$ EDITORIAL}

This Special Edition of $A S E M K A$, a bilingual literary journal of the University of Cape Coast, is published in honour of Prof. Atta Gyamfi Britwum, a revered Associate Professor of Francophone African Literature and Civilisation in the Department of French, U.C.C. It contains twenty (20) papers centred on diverse areas of teaching and research in the Humanities and on the theme of the Conference - Literature and the Humanities in the 21 Century: Interdisciplinary Perspectives - held in his honour by the Department of French, University of Cape Coast, Ghana, $13^{\text {th }}-15^{\text {th }}$ Mars, 2019. To reflect Prof. Britwum's area of research interest, the essays are arranged in two sections according to his dominant medium of instruction (French language) and speciality (Literature and Civilisation), followed by those in English language. The first section consists of a set of nine (9) essays in French spanning between themes in Literature and Language. The second section is made up of a set of eleven (11) essays in English which examine issues in literary studies, Language and Didactics, ICT and French Education, Philosophy, and Translation, among others. This special arrangement is however representative of the bilingual nature of the Journal.

\section{First Section}

Britwum, A. G.'s paper titled, “Insuffisances Théoriques Des Damnés De La Terre De Frantz Fanon", presents the Fanonian perspective as a complement to the African nationalism that informed anticolonial struggles. The study posits that African nationalism, populist in nature, for failing to target the capitalist economic base, which defines colonialism, ended up strengthening it. It concludes that Fanon's anticolonialist perspective, despite its overt radicalism, is not designed to allow a "bottom-to-top change" in colonial / capitalist society.

Kodah, M. K.'s paper titled, "Disculpation de Dieu dans le malheur des hommes: Une lecture critique de Gouverneurs de la rosée de Jacques Roumain", puts into question the responsibility of God in the suffering of men on earth and the capacity of man to make and unmake himself. The study aims at absolving God of the guilt of the miseries of men, and also questioning the atheistic or anti-religion denunciation of this narrative 
text since its publication. The study is accomplished through a critical reading and a thoughtful analysis of Jacques Roumain's Gouverneurs de la rosée within the analytical structure of literary studies and sociocriticism.

Addo-Danquah, O.'s paper, "Le récit de pensées : Une analyse comparative de Vol de nuit d'Antoine de Saint-Exupéry et La Condition humaine d'André Malraux", drawing inspirations from theorists such as Léon Edel (1961) and later Dorrit Cohn (1981), examines what Antoine de Saint-Exupéry's Vol de nuit by and André Malraux's La Condition bumaine respectively can offer on the side of representations of the interior life. The study is posited within the framework of narratological theories.

Kodah, M. K. \& Togoh Tchimavor, A. A. in "Réactions des femmes face au conflit de genre dans C'est le soleil qui m'a brûlée et Tu t'appelleras Tanga de Calixthe Beyala" examine the reactions of women to gender conflict in Calixthe Beyala's C'est le soleil qui m'a brulée and Tu t'appelleras Tanga. The study critically reflects on the various ways women in Beyala's C'est le soleil qui m'a brulée and Tu t'appelleras Tanga react to oppression and exploitation resulting from patriarchal domination. It therefore examines the sources and nature of this conflict, and how women react to it in the two novels. The study points to the fact that, much as conflict emanating from patriarchal oppression and male's domination in human societies is inimical to the rights of women, the methods used by the latter to free themselves from this state of being remain questionable, in that, these methods defy rational thinking and are also a kind of reversal oppression and domination which are equally unacceptable.

Kudi, M. D.’s paper, “La Littérature francophone face aux médias de télécommunication: Une nouvelle dynamique de la création romanesque, le cas de L'Énigme de retour et Tout bouge autour de moi de Dany Laferrière", seeks to examine how pertinent painting, photography, television, telephone etc. are to the production of the contemporary Francophone novel. The study focuses on L'Énigme de retour (2009) and Tout bouge autour de moi (2011). The analysis is based on the perspective of literary intermediality propounded by Jürgen E. Muller which is characterised by an interaction between telecommunication media and literary text. The study establishes through these selected novels that these media forms are not simply another form of expression in the novel but rather a lens through which the story is narrated. 
Gli, M.'s paper titled, "Les faces du bonheur dans Vol de nuit d'Antoine de Saint-Exupéry", analyses the faces of happiness in Antoine de Saint-Exupéry's Vol de Nuit. The study is conducted through thematic approach. This approach is complemented by Maslow's theory of human needs. The collection of data or the collection of information is purely documentary. The study therefore seeks to establish a link between individual happiness and collective happiness in Saint-Exupéry's selected narrative text.

Krakue, S. P.'s paper, “Christ haïtien : Gouverneurs de la rosée et La Bible", attempts to question Jacques Roumain's Gouverneurs de la rosée in order to elucidate the novelist's use of the biblical text in his creative activity. The study demonstrates that Jacques Roumain's narrative text turns out to borrow biblical ideas not only to develop his plot but also to design his main character.

Afari, E. S. K. \& Yegblemenawo, C. A. A. in “Apports de la télésérie à l'amélioration de la compétence d'expression orale du FLE à l'école normale." examine the impact examine the impact of the use of serial movies as teaching aid on oral expression of French language learners in Colleges of Education in Ghana with the aid of smartphones. The study discovers that the use of serial movies in teaching French boosts learners' performance in oral communication. It therefore recommends that serial movies could be used in teaching French language lessons in order to enhance the oral communication competencies among learners.

Bationo, J.-Cl.'s paper titled, "Didactique de la littérature et littérature didactique : l'exemple de la littérature africaine francophone en classe de langues étrangères au Burkina Faso", shows not only how to teach literature in language class but also how to use didactic literature to develop social skills among learners to reduce vandalism, school violence, negative stereotypes, misunderstandings of intercultural nature while cultivating social peace and living together in a context of internationalization, globalization and digital revolution. The paper focuses on francophone African Literature and posits that methodological approach used for the didactic transpositions of literary content is based on the new orientation and the redefinition of the objectives of language teaching and on the didactic models of the aesthetic reception of didactics of literature which requires putting the learner in intensive interaction with the text and motivating $\mathrm{him} /$ her to express himself/herself on his/her reading experiences. 


\section{SECOND SECTION - ENGLISH}

Krakue, S. P.'s paper titled, “Quod erat demonstrandum: A comparative study of narrative technique in Ama Ata Aidoo's Changes and Albert Camus' Les justes (The Just Ones)", demonstrates through textual analysis, how in Ama Ata Aidoo's Changes and Albert Camus Les justes, the authors resort to a specific form of irony to bring the discussion of issues raised to a conclusion. The technique consists in demonstrating clearly a huge discrepancy between a "fine" idea and its practical usefulness. Both authors successfully use narrative technique. Albert Camus demonstrates the hollowness of the idea of fighting for justice through revolutionary violence and Ama Ata Aidoo similarly demonstrates the fatuousness of the theory of women-emancipation-through-polygamy.

Adjandeh, E. A. analyses selected reports in Ghanaian media in relation to the clergy and identifies how Wole Soyinka's theme is reflected in these media in her paper titled, "Analysis of Wole Soyinka's Trials of Brother Jero in Relation to Ghanaian Religious Discourse". The study seeks to examine the extent to which themes in Soyinka's Trials of brother Jero play out in religious discourses in Ghana. The global nature of the issues problematized by Wole Soyinka also comes out through this study as the work set in Nigeria is analyzed in relation to the selected articles set in Ghana. The paper relies on a content analysis of Trials of Brother Jero and similar themes presented in the selected articles, and makes a few recommendations on how these religious issues could be partially, if not wholly, resolved in Ghana.

Sam, C. A.'s paper, "Decolonizing the Postcolony: Of Men, Spatial Politics and the New Nation in WA Thiongo's Wizard of the Crow", examines how Ngugi Wa Thiongo's Wizard of the Crow blatantly explores Africa's complicity in a seemingly cyclic colonization in the $21^{\text {st }}$ century and its attendant consequences for the total liberation of Postcolonial Africa. The study examines the correlation between masculine representations, spatial reorganization and futurity as alternative ways in thinking about Africa's future through Bakhtin's theory of the carnival and other such concepts as polyphony and the grotesque. The result of the analysis is that the correlation between forms of communities and forms of masculinities is an indication of a vision of hope for Postcolonial Africa. 
Kambou, M. K. \& Traore, S. A. in "Manipulation and the popular uprising in Burkina Faso in 2014", analyse the different discourses in the build-up to the popular uprising in Burkina Faso on the $30^{\text {th }}$ and $31^{\text {st }}$ October 2014. It attempts to clarify how political and civil society leaders use language and other non-linguistic elements to influence the ordinary citizens' minds and, indirectly, their actions. The analysis is premised on Van Dijk's (2006) Sociocognitive approach. The paper analyses the cognitive, the social and the discursive dimensions of manipulation in six political speeches (two speeches from Civil Society, two from the ruling party and two from the political opposition). The results suggest that the three groups manipulated their audiences, and finally, the ruling party lost following the resignation of the then Head of State, making way for a Transition government to take over the reins of governance.

De-Souza, A. Y. M.'s paper “'Test-taking Strategies of University of Cape Coast Students of French as a Foreign Language: a Case Study.” seeks to provide a description of test-taking strategies that may inform teaching and learning of French for better output in tests against the background that Ghanaian students of French as a foreign language deploy strategies that are not adequate enough in answering test items in French. The study examines data gathered right after a French test by level 200 students, using recollective verbalization protocols.

Kambou, M. K. \& Soma, L. examine in their paper titled, "Local Culture and EFL Vocabulary Learning”, the influence of learners' culture on foreign language vocabulary. The paper seeks to demonstrate that there is a link between culture and lexico-semantic errors committed by learners of English as a foreign language among Dioula speaking students in Burkina Faso. A language test composed of two written activities was used as the data collection instrument. The results revealed that the Dioula speakers' English is influenced by their culture. These results have some pedagogical implications. They, therefore, suggest that we adapt the teaching of EFL vocabulary to learners' culture.

Kabore, A. \& Nazortin, C. in "Critical Analysis of the Place and Importance of Literature in the Teaching / Learning of English and in School Leaving Certificate Examination in Burkina Faso from 1985 to 2018", analyse the types of texts given at the "Baccalaureate A" written examination in the last thirty years. In this study, quantitative and qualitative 
data are collected. Baccalaureate written English papers are the main focus of our collection. Teachers and supervisors are interviewed. The study is grounded on "Reader-Response Theory" which stresses the interactions between the reader and the text. The results of the study show that the great majority of texts proposed for "Baccalaureate A" examination, in the last thirty years, are non-literary texts.

Malgoubri, I., Sawadogo, M. \& Kambou, M. K.’s paper titled, “Digital Audio-visuals Aids and Listening in English as a Foreign Language Classrooms", is an experimental study which investigates the potential of digital audio-visuals to improve the listening skills of EFL learners in secondary schools in Burkina Faso. On the assumption that learners born around the year 2000 are digital natives, the researchers try integrating smartphone-friendly audio-visuals in their EFL classrooms in a four-week experiment involving one Experimental Group and one Control Group. The experiment aims at gauging the effectiveness of those aids operated via students' smartphones in improving learners' listening and speaking skills. Independent T-tests were used to compare the groups and Sample Paired TTests to make comparisons within groups. The study suggests that, if appropriately used, smartphones are excellent devices for language teachers and learners in this digitizing world.

Osei, R. N. \& Inusah, H.'s paper, “A Critique of the Images of Heaven in the Scriptures of the Abrahamic Religions: An Existentialist Perspective." Critically examines the scriptural images of heaven as captured in the Abrahamic religions - Judaism, Christianity and Islam - from the existentialist perspective. The paper argues that the idea of life beyond this earthly existence for all human beings in a specially prepared location by God for eternal happiness for those who obey His commands on earth called Heaven, as propounded by the Abrahamic Religions, throws up a lot of problems, especially from the existentialist perspective. The study concludes that the scriptures' constructs of heaven appear self-contradictory and fail to strike a chord with the contemporary image of the ideal society when perused from the existentialist perspective and should, therefore, be discarded.

Negedu, A. K.'s paper "Lexical Gaps and Ideological Shift in the Translation of Chinua Achebe's Things Fall Apart as "Le Monde S'effondre" in French." examines the ideological divergence between the title of the original text and the title of the translation, following an observation 
that in translating Chinua Achebe's Things Fall Apart, Michel Ligny translates directly Igbo terminologies, realities and beliefs into the French language. The paper concludes that the ideology that the translated title projects to French-readers is totally different from the ideology that the original title projects to English-readers.

Talburt, T., in "Political Transformation and Development in Africa: Lessons from Achebe's Things Fall Apart", formulates critical perspectives on the significance of Achebe's novel for the socio-political and economic transformation and development of the African continent. The paper challenges one of the central assumptions in this story that Africa falls apart as soon as it comes in contact with Europe. It questions aspects of political conservatism exhibited in Okonkwo who is suspicious of fundamental changes to his society. The discussion is based on the jollof rice principle of political hybridisation of development which proposes the amalgamation of Westernised and non-Western ideas and systems, in order to achieve economic development, rather than totally rejecting Westernisation in its entirety. The study uses examples of Western-style democracy and State intervention in Africa to demonstrate the significance of embracing some aspects of Westernisation through political hybridisation. 




\title{
Decolonizing the Postcolony: Of Men, Spatial Politics and the New Nation in wa Thiongo's Wizard of the Crow.
}

\author{
Christabel Aba Sam \\ University of Cape Coast, Cape Coast, Ghana
}

\begin{abstract}
The advent of democracy - and in particular multi-party democracy - was thought to be relieving for Africa, especially in terms of the desire to undo the damage of colonialism. A careful look at Postcolonial Africa today, relative to the desire for economic and political freedom, reveals conditions that suggest that not much progress has been made. Ngugi wa Thiongo's Wizard of the Crow blatantly explores Africa's complicity in a seemingly cyclic colonization in the $21^{\text {st }}$ century and its attendant consequences for the total liberation of Postcolonial Africa. Employing Bakhtin's theory of the carnival and other such concepts as polyphony and the grotesque, this paper examines the correlation between masculine representations, spatial re-organization and futurity as alternative ways in thinking about Africa's future. The result of the analysis is that the correlation between forms of communities and forms of masculinities is an indication of a vision of hope for Postcolonial Africa.
\end{abstract}

Keywords: Africa; Carnival; Futurity; Masculine Representations; Polyphony; Spatial Re-Organization.

\section{Introduction}

'Just as today is born of the womb of yesterday, today is pregnant with tomorrow' Ngugi wa Thiong'o (Wizard of the Crow)

A critical reading of Ngugi wa Thiong'o's texts reveals a careful and consistent trajectory towards decolonization. From the publication of Weep not Child to his penultimate, Wizard of the Crow, Ngugi has been committed to 
prompting the need for a thorough re-assessment of the colonial and postcolonial politicking despite the disapproval of some postcolonial thinkers. In Decolonizing the mind: The politics of Language in African Literature (1986), Ngugi draws attention to the inherent paradoxes in postcolonial liberations - drawing attention to the content of the mental habits of postcolonial subjects as a reinvention of the colonial experience. Thus, in Wizard of the Crow, Ngugi problematizes the political configurations inherited from colonialism and radically revisions the possibility of a new Africa. He satirizes what appears to be an impossible future - ridiculing the contradictions in the quest for a new postcolonial state against the back-drop of neo-colonialism (emphasized in the dictatorial new multi-party dispensations) and globalization in Africa. To this end, Ngugi provides an allegorical image of how Africa's potential is continually captured in an era of globalization.

Wizard of the Crow is a story of a dictator who is simply referred to as the Ruler. He is the second ruler of the Free Republic of Aburiria; a prototype African country. Although his power is limitless, his minions desired to further consolidate his messianic zeal in the proposed Marching to Heaven project which is supposed to be a super world-class edifice of a rare quality. Marching to Heaven would allow the Ruler to have direct communication with God, so that the Ruler would be next to God. When all the strategies to get the Global Bank to sponsor this project fail, the Ruler becomes frustrated and subsequently develops a bizarre condition. As the story progresses, we encounter two beggars: Kamiti and Nyawira, who eventually become partners in divining the fortunes of the Free Republic of Aburiria. Kamiti and Nyawira carefully restore the voices of the people of Aburiria through a series of counter-struggles with the Ruler's minions.

While several scholars have paid attention to the colonial legacy and the refracted African state, focusing on the tragic experiences of slavery and colonization even after the wake of independence (Oluwafisayo, 2014; Ogagaghene, 2010; Chakrabonty, 2012), others have also focused on the identity politics (Waita, 2013) and how Ngugi devises resistance mechanisms in order to empower the African woman in a male dominated society (Sadek, 2014). Employing Bakhtin's theory of the carnival and other such concepts as polyphony and the grotesque, the present essay demonstrates the ways in which the successes and failures of Ngugi's male characters become meaningful within the context of Africa's future. Again, I examine how Ngugi re-imagines the postcolonial nation through the transgressive acts of Kamiti and Nyawira as collaborators in search for freedom. The heartless despot Ruler of Aburiria and his sycophants remain a distasteful reality Africa must confront in order to consolidate the defining freedom of the postcolonial state. Although the focus of this paper is on the correlation between masculine 
representations, spatial re-organization and futurity, the heroic role of Nyawira (a female character) cannot be over-emphasized. The character of Nyawira does not simply indicate the author's feminist vision (Waita, 2013).

Rather, Nyawira corroborates the author's desire for balance and collaboration in a new Africa renaissance. Ngugi appears to favour femalemale ideals as a necessary future factor. In other words, Ngugi appears to suggest that our visions of a new Africa must be founded on unity and a conscious balance - a theme that is hinted at and explored in Adichie's Purple Hibiscus especially in the coexistence of Father Amadi and Auntie Ifeoma as masculine and feminine fusion in Nsukka. The paper is structured into four main parts: the first part deals with the character of the Ruler and the problems in his masculine ideals. The second section which is titled, 'Dictatorial and /or Democratic Spaces: The Free Republic of Aburiria and the Birth of Baby 'D" looks at how Aburiria improves qualitatively, from dictatorship to a semi-democratic dispensation and how this transformation intimates the possibility of hope in the postcolony. In 'Visions of tomorrow and Postcolonial therapeutics', I comment on Ngugi's projections for the new nation and how a conscious healing of the past and toxic masculine ideals will enhace the fortunes of postcolonial Africa. The fourth and final section will constitute the concluding part of this paper.

\section{Spatiality}

The concept of space is a relational one. More often than not, it is conflated with the idea of place, and time (Upstone, 2009). Particularly, the dimensions of 'place' as a location and an idea become crucial (in terms of how individuals become defined by geographies and how such persons come to understand the world) since place is often substituted with space as a duality. As Said (1978) suggests, the idea of space has been interpreted on the basis of dualities; East and West, colonizer/colonized; oppressor/oppressed; male/female; socialist/capitalist. So that there is an attempt to interrogate how the problematic of imperialism compels new forms of identities. In other words, the colonial discourse becomes central as far as postcolonial spatial politics is concerned. Ashcroft (2009) defines postcolonial space as: "A place which signifies colonial and offers a more fluid and open form that the imperial attempts to obscure." (p. 97)

In other words, embedded in the idea of postcolonial spaces is an ambivalence of contestation and renegotiation. It means that, there is an attempt to break with colonial definitions of being and a subsequent radical reassertion of new modes of being. It is important to recognize that the emphasis of newness is not restricted to a radical destabilization of what the 
colonial offers but also a modest bridging of both forms. Bakhtin's theory of the carnival offers an opportunity to deal with subjectivities and intersubjectivities in a given space. There is the chance to have a new outlook on the world, to realize the relative nature of all that exists, and to enter a completely new order of things.' (34) Thus, in carnival, all the existing rules and norms are disobeyed - there are no limits to acceptability. That is, anything and everything is permitted. Two key concepts inform the analysis in this paper; polyphony and grotesque realism. Polyphony literally means 'multivoicedness'. It is an unrestricted interaction between characters. So that there is no one voice privileged over another. In the context of the novel, we find that Ngugi tries to conflate imperialism and dictatorial rule with monologism, the authoritarian voice of the Ruler and therefore the possibility of alternative voices constitute an impulse for newness. Again, the principle of the grotesque according to Bakhtin is that which is opposed to anything that is static or permanent. It is a way of critiquing the world through human anatomy so that certain parts of the body are purposefully exaggerated, debased and degraded in order to expose the absurdities. Such degradation and debasement are usually meant to bring down to earth polished or finished images in other to show their arbitrariness and vulnerability. It is in this degradation that we find the birth of newness (Case, 2015). It is interesting to note that the principle of the grotesque permits an understanding of the Free Republic of Aburiria and her leader as a metaphor for showing how the writer mocks African leaders, key institutions and establishments that appear to be fighting in the interest of its citizenry.

\section{Men in Transition: Male Daemons, Power Daemons and Rebel Daemons}

The Free Republic of Aburiria as a prototype African country is typically male dominated. Men are the owners of everything including women. In Aburiria, men are notorious for having multiple homes, some official, others on the side (p. 302). And so issues of maleness are tied to having multiple women as bed makers, wife-beating is a male prerogative and all other subservient female roles enhanced the ego of the men in Aburiria. Aburirian masculinity is defined by the quest for power, wealth and most importantly, the desire for white American maleness. 'In fact, it was the desirable ideal' (p. 741). The second Ruler of the Free Republic of Aburiria personifies Aburirian masculinity. The entire Aburiria lived in awe of him. They trembled at his presence for his word was the law. 
The person who would ever dare to challenge his authority has not yet been born and if he has, he still has to change himself into a spirit and grow a beard and human hair on his feet. You did not know that did you? (p.11)

The Ruler, His Holy Mightiness, Mtukufu Mtakatifu has an imposing personality. He is the dream of all the men in Aburiria; he had three wives, three sons and two daughters.

The Ruler was very protective of his bed-makers. He did not want to know of any other person having touched them before or after him. How many husbands had he exiled abroad, giving them jobs far away that he might have unfettered access to the women? (p. 410).

The Ruler is a self-centered, greedy and a promiscuous man. He apparently assumes the headship in every household. The Ruler of Aburiria is the might and the light of Aburiria; the sole voice of the people. He and the country are one and the same. Everything revolves around him. He is the standard for 'respectable' maleness. It is a real honour to be noticed by the Ruler; no wonder Machokali, Sikiouku, Big Ben Mambo and a host of others willingly decide to be maimed at the pleasure of the Ruler. The long-standing rivalries between these sycophants therefore, are pointers of their fantasy. Despite his unquestionable authority as a typical hegemonic African male, the Ruler with his loyal ministers displays a fantastic desire for a more superior masculine identity - white American maleness. This desire which is by no means provoked by colonial consciousness is diagnosed as 'White-ache' by the Wizard of the Crow (a postcolonial diviner). 'White-ache' is characterized by a symptomatic coughing of 'Ifs' and 'Ifness' indicating a certain level of restrain in voicing an intimate desire. This restrain, apparently, is as a result of a troubled consciousness not to resign oneself to inferiorities.

Titus Tajirika is the first to be struck by this malady of words. After his rise to the position of the Chairman of 'Marching to Heaven' - an envious position although incomparable to that of the Ruler, Tajirika could not bring himself to imagine the prospect of a better office; overwhelmed by the three sacks of money he got from business introductions few minutes after the announcement of his appointment, words got stuck in his throat and Vinjinia his wife brings him to the diviner for a cure:

The voice of the Wizard of the Crow now seemed to issue from inside the mirror: "vomit the words, the good and the bad" $[\ldots]$ 
If ... my ... skin... were... not... black! Oh, if only my skin were white!" $[\ldots]$ As he looked into the future, he suddenly realized that at the rate money was coming in he would end up being the richest man in Africa, and the only thing missing to distinguish him from all the other black rich was white skin. He saw his skin as standing between him and the heaven of his desire. When he scratched his face, daemons within were urging him to break ranks with blackness and enter into union with whiteness. In short, he suffered from a severe case of white-ache. (pp. 179 - 180)

Tajirika's dream of a great future appeared to him as bleak and impossible due to the colour of his skin. Indeed, his black skin was for him limiting, an impediment, and almost a ruin because he appreciated the difficulty in undoing 'blackness'. It created in him some kind of inferiority which has become a common disease in postcolonial Africa. The chronic nature of this disease, inferiority complex, is its ability to refract identity and retard growth - forcing one to become a willing slave to a presumed superior. The treachery in these thoughts pursues Tajirika until he finally turns himself into an ogre. As Fanon argues, the black man suffers an inborn complex that makes him feel impure and inadequate despite the fact that he (the black man) shares the same ontological morphology with the White man. Thus, experiencing being, the black man develops a fetish for a superior self which is solely located in the White world. This negative self-perception, as Fanon argues, is inherited from a colonial cycle (Fanon, 1968). Ngugi appears to suggest that this mental condition of colonized subject brews a degree of self-insecurities that can only be eroded through a conscious reconstitution of the self.

After his rise to power as the imperial ruler of Aburiria, his secret desires remained a top priority. He succeeds in acquiring a white right arm and a white left leg in order to transform his body into a white man until tragedy struck:

Tajirika was making preparations to return to America for the other body parts to complete his transformation when he read in a newspaper that the clinic had been closed because it was not licensed. [...] So, despite his incomplete state and loss of money to boot, Tajirika dared not complain, remaining a man in transition with a white left leg and white right arm (p. 742)

While Tajirika remains in transition, the second Ruler of Aburiria also entertains such treacherous thought despite his 'absolute' power. He (the 
second Ruler of Aburiria) has a passionate desire to become white, for he too believes that to attain ultimate manliness with absolute respect, one has to be white. As a result, when the Ruler fails to secure the loan for 'Marching to Heaven' despite his personal involvement in the lobbying of the Global Bank in New York, he becomes disfigured by the harrowing thoughts of his deflated authority. He develops a strange pathological response. His body inflates; what is diagnosed as 'Self-Induced Expansion'. Ngugi's disenchantment with these deceitful desires is carefully encapsulated in the strangely degrading bodies of these men. The exaggerated body of the Ruler is a profound ambivalence that points to rot and renewal in the postcolonial African state. To this end, I deploy Bakhtin's notion of the grotesque in order to disclose the anticipatory discourses that undergird the exaggerated body of the Ruler. The notion of the grotesque indicates:

A body in the act of becoming. It is never finished, never completed; it is continually built, created, and builds and creates another body' (Rabelais, p. 317). The grotesque body is a form of life-in-death, a perpetual rebirth: the body "swallows the world and is itself swallowed by the world" in an ongoing cycle of eating, drinking, defecating, copulation, pregnancy, and birth (Rabelais, p. 317).

The Ruler, in his own state of expansion, is rumored to be pregnant; reflecting on this rumor, the Wizard of the Crow asks, "to be pregnant is to carry a seed of becoming. Is it of life or death?" (p. 680). Indeed, the Ruler was pregnant with an unfamiliar seed - the trauma of his failure with 'Marching to Heaven' and the desire to restore his waning authority had become boxed into unfamiliar desires. It is important to recognize that Ngugi tries to ridicule the desire for White American masculinity as a desirable ideal - he considers it an erroneous image of acceptable maleness which is why these men are physically deformed - stressing it unsuitability.

It is also very important to interrogate why the Ruler's sycophants disappear. Machokali and his rival Sikioukuu are made to disappear in order to terminate the reality of such desires. They had almost become incarnate of the Ruler and therefore their continued existence will mean a recycling of unacceptable maleness. Thus, their disappearance is an indication of Aburiria's readiness to discontinue the hegemony of the nation-state and also to make ineffective patriarchal structures that inhibit their freedom. These men (The Ruler and his minions) start off and remain orthodox males - despite the stiff challenge from Nyawire and the women of the peoples' court. They are unable to appreciate and accommodate the potential of the female sex and 
therefore the revisions of the new Aburiria. They are bent on remaining male daemons.

Kamiti (a young man who for the frustrations of job-seeking 'poses' as a diviner and is referred to as wizard of the crow) remains Ngugi's revelation of the new man because he does not become co-opted in the increasing pathological betrayal of the African identity. His masculine ideologies are in contradiction with that of the Ruler and his sycophantic ministers. No wonder his masculine performance is considered a rebellion to the state. Kamiti appreciated his African identity as equally authentic amongst other authentic identities and therefore he believed in the self-worth of every individual. In fact, Kamiti exposes the monstrosity and treachery in accommodating such ideological essences of black inferiority and the fact that a continued affirmation of white superiority further cripples the potential of the new nation.

Kamiti is symbolic of Africa's communal heritage and pluralism. Unlike the Ruler and his minions who were selfish, dubious and reckless putting their individual interests ahead of the nation, Kamiti demonstrates a commitment to democratic principles when he purposefully encourages his clients to voice their desires. It is important to recognize that we find in Kamiti's nature a different kind of balance outside of male-female principle; his belief in the union of the sexes and his collaboration with Nyawira which was the prelude to Aburiria's freedom. Kamiti also showed a cultural balance. When Kamiti is invited to America to help with the Ruler's ailment, Dr. Furyk and his colleagues are marveled at his (Kamiti) appearance and disposition when he admitted to be a postcolonial witch doctor. He was not in the usual tatters with scary drawings on his face.

The deviation is implicitly profound as it apparently tells us of Ngugi's subtle endorsement of mimicry rather than a radical destabilization of the colonial heritage. Thus, Kamiti's success in blending scientific and indigenous approaches in wizardry is indicative of the new times. And so for Ngugi, the success of the new postcolonial state is not only premised on balance between the external (West and the East) or a hybridized culture but also a bridging of the sexes so that akin to Mbembe's (2001) concern which is that within the binary opposition itself lay certain internal imbalances in terms of creating and recreating stereotypes. In other words, what Mbembe suggests is that it is not helpful to understand postcolonial relations in terms of dissimilarities.

Rather, it is important to understand the ways in which postcolonial subjects interrogate their identities which have more or less become their colonial legacies. Thus, what Ngugi appears to suggest is the fact that the new postcolonial state, as we envisage, must form cohesive identities as far as the dynamics of gendered spaces are concerned. Again, the new postcolonial state 
must go beyond binary categories; specifically, there must be collectivity (exemplified in the collaboration between Kamiti and Nyawira) and belongingness such that gendered spaces will be bridged by feelings of community. Chakraborty (2012) substantiates the fact that Kamiti and Nyawira resist the hegemony of the nation-state through their mock wizardry and dance performances so that the two characters become Ngugi's model of good governance and progressive leadership. esides the issues of gender complementarity which proves to be an essential for the emergence of the new nation-state, we find that the collaboration between Nyawira and Kamiti provokes a new politics of revolution where colonized/marginalized subjects manoeuvre their way back to the centre despite opposition. While the patriarchal climate in Aburiria continues to be obscure and unsafe for women's emancipation, Nyawira breaks the stereotypes of female timidity and subordinations. Her belief that the condition of a woman in a nation is the real measure of its progress and that you imprison a woman and you have imprisoned a nation (p. 253) strengthens her desire to reclaim the voices of women (and men ) from the clutches of the power deamons in Aburiria. Her attempt at abducting Titus Tajirika and her agentic role in the eventual abandonment of the Marching to Heaven projects re-engineers a new path of progress for a new Aburiria.

Kamiti believed in democracy - his attempt at purposefully guiding his clients to voice their intimate desires and the fact that he appreciated the contributions of the woman as a necessity for progress puts him ahead of his fellow men. Kamiti's masculine disposition rejects all forms of 'foreign' thinking and its content and thus reiterates Ngugi's demand on overthrowing white superiority and re-asserting the African identity.

\section{Dictatorial and/or Democratic Spaces: The Free Republic of Aburiria and the Birth of Baby ' $D$ '}

In discussing the spatial dynamics in Ngugui's Wizard of the Crow, we will realize that the idea of transformation is not predicated on shift in physical location. Nonetheless, spatial influence on behavior is achieved through a single qualitatively improved space. The Free Republic of Aburiria was a prison of hopes and dreams. None of its citizenry dared to say anything except it was in praise of the Ruler and the country - The Ruler and the country shared the same denominator. It became so unsafe a place that dreams and desires were carefully guided not to travel beyond the heart. Thus, we notice that even the so-called political actors (the Ruler's minions) were struck with the malady of words - the inability to voice one's desires. Aburiria was dominated by the sovereign voice of the Ruler whose voice was the authentic 
voice and therefore the visibility of any other voice meant a strange resistance of the established order. And so it is not strange Machokali announces that:

The Aburirian masses are ready to forgo clothes, houses, education, medicine, and even food in order to meet any and every condition the Bank may impose on the funds it releases for Marching to Heaven. Upward ever, Downward never. That is our new slogan. We will not rest until we get to Heaven's gate. We swear by the children of the children of our children to the end of the world - yes, we swear (p. 203)

The Free Republic of Aburiria would stop at nothing until she sees her Christ-like Ruler communicate directly with God and that is why the Ruler and his sycophants paused at nothing to frustrate the activities of the Movement of the Voice of the People (MOTVOTP). The Movement of the Voice of the People is a band of female pressure group poised to restore hope into a fast collapsing nation under dictatorship. Considering the political hegemony in Aburiria, the activities of MOTVOTP becomes significant. Their approach to announcing their disgust about the Ruler's depraving project at the celebration of his birthday hugely threatens the unopposed image of the Ruler.

And then just as planned', Nyawira told Kamiti, 'all of us in the arena suddenly faced the people, our backs turned to the platform. All together we lifted our skirts and exposed our butts to those on the platform, and squattered as if about to shit en masse arena. Those of us in the crowd started swearing: MARCHING TO HEAVEN IS A PILE OF SHIT! MARCHING TO HEAVEN IS A MOUNTAIN OF SHIT!'And the crowd took this up. There were two or three women who forgot that this was only a simulation of what our female ancestors used to do as a last resort when they had reached a point where they could no longer take shit from a despot; they urinated and farted loudly. May be need or fear overcome them or both. (p. 250)

The message of the women dance troupe was loud and clear. They were simply tired of the despot of a Ruler who cared not a thing about his people except things that boosted his ego. Their performance mirrored their absolute disgust for his dominance - they exposed the stench that had engulfed them and the potential of the stench to chase out the very people that caused it. It was clear at this point that not everyone in Aburiria was in favour of his 
mountain of shit as the women called it. We realize that the audacity of the women struck the Ruler to a point that there was absolutely nothing he could do to undo the stain in his weakening authority. The bit of the black humour remedy could not save him from the shame. The counter-spectacles of the Movement of the Voice of the People gradually succeed in flattening the bloated image of the Ruler. It is important to note that the performance of the women dancers does not merely challenge the masculine ideals of the Ruler neither does it simply demolish the vertical structures between the powerful and the commons in Aburiria. 'It espouses a possibility for a better futureperhaps a future without the despotic Ruler-by exploring the regenerative aspects of the abusive, the bodily and the scatological' (Grzeda, 2013). This is because according to Bakhtin, reference to the lower parts of the body, such as "the genital organs, the belly, and the buttocks," is a characteristic feature of "grotesque realism". The idea of the grotesque which is:

To degrade also means to concern oneself with the lower stratum of the body, the life of the belly and the reproductive organs; it therefore relates to acts of defecation and copulation, conception, pregnancy, and birth. Degradation digs a bodily grave for a new birth; it has not only a destructive, negative aspect, but also a regenerating one. To degrade an object does not imply merely hurling it into the void of nonexistence, into absolute destruction, but to hurl it down to the reproductive lower stratum, the zone in which conception and a new birth take place. Grotesque realism knows no other lower level; it is the fruitful earth and the womb. It is always conceiving. (p. 21)

The idea of the grotesque shows how the imperfections of the body defeat the idea of absolutes and exactness. Thus, to degrade means to downplay the idea of superior self so that the self is defined by both limitations and possibilities. In other words, the grotesque humbles all that is elevated and, in the process, create an opening for renewal. Hence, the performance put up by the women of Aburiria is a carnivalesque performance which serves as a subversive strategy to expose both patriarchy and the rot that had engulfed Aburiria - demolishing dictatorial rule and male chauvinism and preparing the cradle for the arrival of 'Baby D'. The images of 'fart', 'shit' and 'urine' explain these bodily excretions as residues so that the image of the Ruler is undermined and further devalued by the stench these bodily excretions produce. It is important to emphasize that underneath this devaluing of the Ruler's image is an opportunity for reformation. So that what is born out of the Ruler's old self becomes characteristic of the new man. In 
other words, the notion of the grotesque beyond the subversive is also the regenerative feature. Thus, the women's performance has an ultimate objective beyond the mundane act of criticism. It looked forward to the regeneration or the renewal of the Republic of Aburiria. What they are intimating by their carnivalesque acts is a spatial regeneration or renewal so that the politics of shit will be done away with. In other words, they intimate a qualitatively improved space where equality as the basis of democratic principles prevails.

In his bid to consolidate his statesmanship, the Ruler of Aburiria resigns himself to accommodate other voices however disgusting. Baby ' $D$ ' (Baby Democracy - the new system of governance in Aburiria) had been induced - it was so infantile and immature because it had become a necessity to ensure being in favour with the West. And so despite its potential towards community, it had become the benchmark for global aid. The Ruler is pressured to embrace democracy just so he could access support from the Global Bank- an obvious burden of the postcolonial state. Certainly, Ngugi does not deny the potential of democracy. Rather, he appears to ridicule the posture of the West as far as dictatorship is concerned and the fact that Africa's independence is simply a new form of imperialism. He indicates that while the West appears to frown on dictatorship, they remain the dictators to several democratic African governments. It has become usual how foreign aid is continually tied to one requirement or the other from the West; colonial masters controlling the economies of their former colonies all in the name of globalization. For Ngugi, 'matured' independence is premised on participatory democracy, psychological freedom and the fact that Africa becomes self-reliant in all areas.

Aburiria could no longer remain monologic because of the Ruler's desire to be in favour with the West and also that the countless confrontations with the Movement of the Voice of the People had made it impossible for the Ruler's Aburiria to remain dictatorial. Authoritarianism had gradually faded and the voices of the people restored. While the role of the Movement of the Voice of the People is important in the liberation of the people of Aburiria, the Wizard of the Crow's contributions to Aburiria's emancipation is also important. Through his divination, the Wizard is able to guide his clients to voice their repressed desires - allowing them the opportunity to differentiate between reality and illusions. Notice how the Wizard (Kamiti) persuades his clients to voice their thoughts, both the "good and the bad." He does not prescribe remedies to their problems; which is quite usual of medical consultations, robbing them of their voices. Rather, the Wizard always creates an enabling atmosphere in which his clients are able to express themselves and make informed choices as well. This becomes extremely significant when we consider the fact that he empowers the people of Aburiria with the impetus to 
voice freely what had long been blocked for several reasons. The democratic spirit with which the Wizard does this can be considered as his commitment to democracy and pluralism. To quote Chakraborty (2012), 'The Wizard's performance becomes politically subversive, and thereby, symptomatic of an opponent to the dictator in the struggle' (p. 5).

\title{
The diagram below gives a graphic summary of the spatial configurations in Ngugi's Wizard of the Crow
}

\author{
THE FREE REBUPLIC OF ABURIRIA
}

\section{Dictatorial Space - it was imperial and sychophantic.}

Introduction of dissenting voices by the women's court through the operations of the grotesque and external influence from the Global Bank.

\section{Democratic Space (Baby 'D') - It is multi-voiced despite the illicit} presence of Western influence.

Two forms of masculinities emerge based on the spatial distribution in the novel. Aburiria under the dictatorial leadership of the Ruler and his men is defined by cacodoxy- erroneous opinions of masculinities. The Ruler and his men see their African orthodox-hegemonic masculine status as limiting despite the privileges it attracts and therefore make deliberate attempts at attaining a much superior masculine identity. Their failure, represented through the writer's use of grotesque bodies is to ridicule the origins of such desires and propose a redefinition of what constitutes acceptable maleness in a postcolonial context. Acceptable maleness in a postcolonial context, as I argue, is devoid of such influences as patriarchal hegemony and white superiority.

Aburiria under baby-democratic rule is characterized by a preferred balance of gendered energies. The collaboration between Kamiti and Nyawira constitute a re-definition of acceptable Africa masculinities. While Kamiti's 
masculine performance remains ideal in terms of the ways in which his masculine identity deviates from the dominant hegemonic apparatus in Aburiria, Nyawira's character role as a schema for a resignification of masculine performances is crucial. To corroborate Stallybrass and White (1986), the character of Nyawira as a 'taboo-loaded' category, demystifies the extremist binary in Bakhtin's classification of the high and the low. Nyawira's agency, as politically and socially transgressive, appears to encapsulate the writer's ideological position that the male-female principle is the route to Africa's progress.

\section{Postcolonial Therapeutics and Visions of Tomorrow}

While Kamiti (the Wizard of the Crow) shows commitment to democracy and pluralism, he also predicts the fortunes of the future nation in his quest to heal his patients. When he is summoned to explain the parable of the Ruler's pregnancy, Kamiti tells us how his search for a more superior black power to heal the Ruler, in time and space, had revealed Africa's disease from the genesis. He found how Europe impregnated some in Africa with her evil;

...these pregnancies gave birth to the slave driver of the slave plantation, who mutated into the colonial driver of the colonial plantation, who years later mutated into the neocolonial pilots of the postcolonial plantation. Is he now mutating into a modern driver and pilot of a global plantation? But Africa impregnated its new breed, which made our people sing, Even if you kill our heroes, we women are pregnant with hope of a new lot $[\ldots]$ so I said to myself: just as today is born of the womb of yesterday, today is pregnant with tomorrow (p. 681)

And so, he conjunctures: "What kind of tomorrow was Aburiria pregnant with? Of unity or murderous divisions? Of cries or laughter? Our tomorrow is determined by what we do today. Our fate is in our hands." (p. 681)

Ngugi assumes the move to globalization as a new order of marginalization of the African continent. What he refers to as 'a blind deity with a double barreled name muting the independence of Africa into dependence' (p. 681). He condemns Africa's typical willingness to let go of her heritage for money and market. How Africa submit to outside powers relegating her moral and social responsibilities to the background. The baggage with developing countries having to condone same sex marriages for foreign aid, international groups and organizations influencing our economic policies are all ways of reducing the autonomy of our independence as a continent. We 
pause to wonder just like the author, why African countries let their wealth meet the needs of those outside its borders and then follow behind with arms outstretched for a loan of the very wealth it let go. Ngugi's prospects of the new Africa thus rely on the struggles to rescue our heritage - a healing of our impregnated souls. Aburiria's future is Africa's future and most importantly the Ruler's sanity since the Ruler and the country were the same. At the beginning of the novel, the Ruler is rumoured to be plagued with five illnesses:

The first was born of anger that once melted up inside him and he was so conscious of the danger it posed to his wellbeing that he tried all he could to rid himself of it belching after every meal, sometimes counting from one to ten and other times chanting ka ke ki ko ku aloud.[...] The second was a curse from a wronged he-goat [...] The third had something to do with the aging of his rule [...] The fourth had its origins in all the tears unshed that Rachael, his legal wife had locked up inside her soul after her fall from his grace. [...] The fifth illness was the sole mark of daemons that the Ruler had housed in a special chamber in the state house, who had now turned their backs on him and redrew their protective services (pp. $3-$ 10).

Ngugi's revision of the new postcolonial state is that which is devoid of a people who are unaware of who they are. Rather they must be a people who are conscious and proud of their origins in order that they might recognize the power they possess in the collective. He perceives 'White-ache' as a disloyalty to African identity and a considerable lack of confidence in the creative potential of the African continent. He suggests that if the African is unable to rid him/herself of this disease (the inability to move beyond the conditional (if), then the African risks the potential of a better future. In other words, 'the possibility to capture the potential in Africa is an open move to community and a demand of our original image' (Wa Thiong'o, 2006). While we detach ourselves from this disillusioned project of the conditional (White-ache), it is important to recognize the danger in sit-tight African governments. While a citizen, the Ruler believed in the fundamentals of freedom and fought for it as an advocate of the people. What happened when he assumed power? This situation has become very characteristic of several African leaders - Gambia's Yahya Jammeh, Cameroon's Paul Biya, Sudan's Omar Al Bashir, Chad's Idriss Deby and Zimbabwe's Robert Mugabe are sorry examples of the failed Masculinist state in Africa. Their aging rule, like that of the Ruler, had replaced vision with hopelessness and so Ngugi assures that so far as Africa continues 
to excuse such monarchic leadership, Africa's democracy will remain a baby i.e. almost dictatorship. In other words, a meaningful independence will be the absence of the politics of hostility and enmity and thus, freeing attempts by the West to control the future.

It is also very important to recognize that Africa's future is incumbent on the ways in which we rethink the foundations of masculine authority. The pain in Rachael's (the Ruler's legitimate wife) soul was because she could not foresee a brighter future with her husband's masculine disposition - defiling the younger generation as a matter of pleasure. The Ruler had no respect for the female gender and therefore using women to gratify himself was typical. This disposition is problematic because it did not afford him the opportunity to appreciate the strength in the union of the sexes and the fact that this unity has a potential for progress. And so sticking to his orthodox orientation meant sticking to stagnation and for that matter staging a revolt against plurality as a mark of democracy. Thus, the failure of the Ruler's regime is predicated upon his obsolete masculine orientation. Kamiti's balance was the springboard for Aburiria's progress. He believed in collaboration and the need to create voices for members of a community. This quality, as I have earlier noted, allows him to free Aburiria from the grips of unfamiliar desires and also offers them an opportunity to appreciate their identities as Africans. It is also important to recognize the author's disgust for a masculinity driven by white bourgeois values. Although Ngugi proposes the need for alternative definitions of masculinity, he is emphatic on the threats of White American maleness. The frustrations of the Ruler and his sycophants are relevant lessons for Africa's growth.

\section{Conclusion}

This paper sought to assess Ngugi's construction of the African male by examining the male characters in his novel. Attention has also been paid to the ways in which he dissects the problems confronting post independent Africa and how these nations can be re-invented; how Ngugi champions the decolonization of Africa's future - calling for a transformative healing of the colonial wound (the loss of identity) and the need to reconcile the African with her origins. He presents Africa in the throes of a strange sickness (White-ache) that seizes her potential. To propose a solution, Baktin's notion of the grotesque is employed to demonstrate how Africa's deformities can be regenerated into possibilities. While the notion of the grotesque helps to expose the rot in postcolonial Africa, it also helps to appreciate the ways in which progress may come to Africa in terms of its inherent ambivalence of degradation and re-birth. We have also argued that Ngugi's revisions of the 
new postcolonial Africa are incumbent on the unity of the sexes - a rethinking of masculine ideologies leading to the desired collaboration for emancipation of Africa.

\section{References}

Adichie, C. N. (2004). Purple Hibiscus; Harper Perennial

Ashcroft, B. (2009). Remembering the Future: Utopianism in African Literature. Textual Practice 23(5), 2009: 703-722.

Bakhtin, M. (1984). Problems of Dostoevsky's Poetics. ed. and trans. by Caryl Emerson Manchester: Manchester University Press.

Bahktin, M. (1984). Rabelais and His World. Indiana University Press, Bloomington USA.

Bhahba, H. (1994). How Newness enters the World: Postmodern Space, Postcolonial Times and the Trials of Cultural Translation. The Location of Culture. London and New York, Routlege. pp. 212-234

Case, M. K. (2015). The Carnivalesque and Grotesque in Modernist Literature: The Final Novels of Ronald Firbank and Virginia Woolf; Florida Atlantic University, Boca Raton.

Chakrabonty, A. (2012). Modes of Resistance in Ngugi's Wizard of the Crow; Rupkatha Journal on Interdisciplinary Studies in Humanities, Vol. IV, No. 2, ISSN 0975-2935.

Fanon, F. (1968). The Fact of Blackness: Frantz. Fanon ad Visual Representation. New York: Grove Press.

Grzeda, p. (2013). Magical Realism: A Narrative of Celebration or Disillusions in South African Literature in The Transition Period. John Hopkins University Press.

Nweze, E. U. (2012). A Stylistic Study of Ngugi wa Thiong'o's Wizard of the Crow and Okri's The Famished Road, university of Nigeria, Nsukka.

Ogagaghene, I. E. (2010). Re-Constructing Identities: History, Trauma and Healing in Postcolonial Narratives; Cornell University Press.

Ousgane, L. \& Morrell, R. (2007). African Masculinities: Men in Africa from the Late Nineteenth Century to Present. New York: Palgrave MacMillan.

Ratele, K. (2008). Analyzing Males in Africa: Certain Useful Elements in Considering Ruling Masculinities; Africa and Asia Studies, 515-536. 
Sadek, S. (2014). The Struggles of African Women in the Selected Works of Ngugi Wa Thiong'o. Taif University: K.S.A.

Said, E. (1978). Orientalism. New York: Pantheon.

Upstone, S. and Teverson, A. (2011). The Politics of Place in Contemporary Culture. United Kingdom : Palgrave Macmillan.

Van der Smith, S. A. (2007). Ngugi wa Thiong'o and the Kenyan Theatre in focus. Namibia: The University of Namibia.

Waita, N. (2013). Identity, Politics and Gender Dimensions in Ngugi Wa Thiong'o's Wizard of the Crow, Chuka: Chuka University.

Wa Thiong'o, N. (2006). Wizard of the Crow: Heinemann

Wa Thiong'o, N. (2006). Decolonizing the Mind: The Politics of Language in African Literature. Portsmouth $(\mathrm{NH})$ : Heinemann. 
